\title{
Identifying Teaching Style: The Case of Saudi College English Language and Literature Teachers
}

\author{
Aisha M. Alhussain ${ }^{1}$ \\ ${ }^{1}$ Princess Nora University, K.S.A \\ Correspondence: Aisha M. Alhussain, Princess Nora University, Riyadh, K.S.A. E-mail: \\ Dr.aisha-hussain@hotmail.com
}

Received: April 9, 2012 Accepted: May 5, 2012 Online Published: July 5, 2012

doi:10.5539/elt.v5n8p122 URL: http://dx.doi.org/10.5539/elt.v5n8p122

\begin{abstract}
The purpose of this paper is twofold. The first objective is to give an account of why I set out to study teaching styles, how I carried out and analyzed a questionnaire survey, what results I got, and what the implications of these results are. The intent is to provide teachers with enough information to help them think about how these findings play out in their own classrooms, thus putting them on track to adapt their teaching style to their students' learning style. The second objective is to see if there is any statistically significant correlation between teaching styles and a number of factors, such as age, years of experience, specialty, and student level. Data analysis showed that literature teachers preferred the all-round flexible style, the mixed style, and the official curriculum and big conference styles successively, whereas linguistics teachers preferred the mixed style, the all-round flexible and straight facts styles, and the student-centered and big conference styles consecutively. No statistically significant correlation was found between teaching styles and age, years of experience, and specialty variables. Whereas statistically significant differences were found between level three and the official curriculum teaching style, and between level four and the student-centered teaching style $(\mathrm{p}<0.05)$.
\end{abstract}

Keywords: teaching style, identifying teaching style, English language and literature teachers, Saudi college teachers

\section{Introduction}

Teaching style can be defined as comprising the roles a teacher plays in the classroom (Grasha, 1997). Our preferred teaching style(s) might be based on the way we were taught, our abilities, and our beliefs about what constitutes good teaching. Some believe classes should be teacher-centered, where the teacher is the expert and authority in presenting information. Others take a learner-centered approach, viewing their role as more of a vacilitator of student learning. One important theory in the Quality Teaching for English Learners (QTEL) program is that of teacher expertise: domains that develop through teaching practice (Walqui, 2010). To build their expertise so as to effectively offer students quality learning and cater to the increasing diversity of student learning needs, English language teachers need to be aware of their teaching styles (Walqui, 2010; Kulinna \& Cothran, 2003).

Through an awareness of their teaching styles, they may gain a better understanding of how best to put into practice their vision of teaching and of how their teaching style can be changed, modified, or supported to improve their interactions with students while maintaining all contextual aspects of teaching. Teaching style awareness may also impact the classroom setting, activities assessment, and teacher/student interactions. After identifying their individual teaching styles, they can analyze ways to highlight their styles to meet students' needs, as well as address any possible areas of weakness in their style and develop a plan to counteract any shortcomings. Teaching style awareness might also reduce teacher-student conflict by matching their styles, especially in foreign language instruction (Felder, 1995; Oxford, Ehrman, \& Lavine, 1991; Wallace \& Oxford, 1992; Zhenhui, 2001). According to Kumaravadivelu (1991), "the narrower the gap between teacher intention and learner interpretation, the greater are the chances of achieving desired learning outcomes" (p. 98).

However, a review of the literature showed that no available studies have investigated the teaching styles of female college English language and Literature instructors in Saudi Arabia or examined the relationship between their teaching styles and their specialties (linguistics and literature). Thus, the purpose of this paper is to explore the teaching styles of Saudi college English and literature teachers and then to investigate if there is any 
correlation between their teaching styles and their specialties, age, student level, and years of experience.

\section{Teaching Style and Inventories}

Teaching style may be defined more precisely as "a teacher's personal behaviors and media used to transmit data to or receive it from the learner" (Kaplan \& Kies, 1995, p. 29). Research has revealed that areas like beliefs, cultural background, teaching experiences, (Heimlich, 1990), the nature of the subject area (Evans, 2004; Lawrence, 1997), government curriculum initiatives (Hargreaves, 2003; Richards, 1998), and job satisfaction (Opdenakker \& Van Damme, 2006) influence teaching styles. Researchers have attempted to design inventories to gauge teaching styles, but to date "little is known about teachers' use and perception of various teaching styles" (Kulinna \& Cothran, 2003, p. 1). Researchers who have investigated teaching styles worked individually, and therefore, a number of dimensions for measuring teaching styles have been developed for different fields: content-centered and people-centered (Robinson, 1979); proactive and reactive (Lenz, 1982); teacher-centered and learner-centered (Opdenakker \& Van Damme, 2006); guided, exposition, and inquiry (May Oi \& Stimpson, 1994); didactic, Socratic, and facilitative (Jarvis, 1985); facilitator and path gnomonic (Rosenfeld \& Rosenfeld, 2007); reproducing and productive (Kulinna \& Cothran, 2003); and holistic and analytical (Evans, 2004).

There are multiple online teaching inventories, such as Cord (2005), Grasha and Riechmann (1996), and Pratt and Collins (2001). One of the most common teaching inventories is the Grasha-Riechmann inventory, which assesses five teaching styles: expert, formal authority, personal model, facilitator, and delegator. Another is the Teaching Perspective Inventory (TPI) developed by Daniel Pratt and John Collins, which assesses several styles: transmission, apprenticeship, developmental, nurturing, and social reform. Mohanna, Chambers, and Wall (2006) designed a tool to raise the awareness of novice teachers about their teaching style: the Six Staffordshire Teaching Styles Questionnaire. These styles are the following:

1. The all-round flexible and adaptable teacher

2. The sensitive student-centered teacher

3. The official formal curriculum teacher

4. The straight facts, no-nonsense teacher

5. The big conference teacher

6. The one-off teacher

Mohanna defined the all-round flexible teacher as one who "can use lots of different skills effectively, can teach both peers and juniors, and is very aware of the way that the whole environment affects both teachers and learners" (Mohanna, Chambers, \& Wall, 2008, p. 23). The sensitive student-centered teacher is "very studentcentered, prefers teaching in small group, with emotions to the fore using role play and drama, and is not comfortable doing straight presentations" (Ibid., p. 146). The official formal curriculum teacher is very well prepared as a teacher and teaches according to the formal curriculum (Ibid., p. 42).

Wall stated that the straight facts, no-nonsense teacher "likes to teach the clear facts with straight talking,concentrating on specific skills, and much prefers not to be involved with multi- professional teaching and learning" (Ibid., p. 53). According to Chambers, the big conference teacher likes "to stand up in front of a big audience and does not like sitting in groups or one to one teaching" (Ibid., p. 62). The one-off teacher likes to deliver small bits of teaching with no support or follow-up.

\section{Method}

\subsection{Procedure}

A questionnaire was designed to investigate the English instructors' teaching styles and collect data about different variables, such as years of experience, age, specialty, and student level, to find out if there is any correlation between these variables and teaching styles. A self-evaluation tool, the Staffordshire Evaluation of Teaching Styles (SETS), was used. It was presented face-to-face to the all the participating college instructors during a seminar. The participants were given instructions on how to rate themselves using the scoring grid and how to put these scores into the six teaching styles diagram. At the end of the evaluation, they were asked to guess their teaching style. All participants were informed of the purpose of the study and showed interest in knowing more about their teaching style and its implications.

\subsection{Participants}

The participants of the study were 18 Saudi college English instructors who taught linguistic and literary courses to different student levels: first, second, third, and fourth. Some of the teachers taught more than one level. Their 
full-time teaching experience ranged from less than 5 years to 30 years, and their ages ranged from 20 to 60 years. Most of them were $\mathrm{PhD}$ holders, while the rest were MA holders. Consequently, the participants represented a broad cross section of teachers. They all used the written form of the self-evaluation tool because it was not available online. Before doing so, they were asked to name their teaching style and describe its nature; however, $100 \%$ of the teachers could not name their teaching style, and only $10 \%$ could describe the nature of their teaching style, which emphasized the importance of conducting this study.

\subsection{Research Instrument}

The Staffordshire Evaluation of Teaching Styles (SETS) is a newly developed instrument by Mohanna, Chambers, and Wall (2008, p. 117). It is a self-evaluation tool with items to be scored on a range of 1 to 5, from not agree at all to strongly agree, respectively. The SETS contains 24 items measuring six teaching styles: all-round flexible and adaptable, sensitive student-centered, official formal curriculum, straight facts, big conference, and one-off. Questions 1, 12, 17, and 20 are measurements for style one; 2, 3, 16, and 19 for style two; $4,8,22$, and 24 for style three; 10,11, 15, and 23 for style four; 7, 9, 14, and 21 for style five, and 5, 6, 13, and 18 for style six. The SETS has a scoring grid; the participants fill in their scores in the correct boxes for each of the questions and then add the scores in the columns to obtain their total score for each of the six teaching styles.

\section{Results and Discussion}

The Staffordshire Evaluation of Teaching Styles (SETS) tool was completed by 18 female college English instructors in Saudi Arabia, who represented a broad cross section of teachers. Of the 18 participants, 4 (22.2\%) had less than 5 years, 1 (5.6\%) had 5-10 years, $11(61.1 \%)$ had $15-20$ years, and $2(11.1 \%)$ had 25-30 years of experience. As shown in Table 1, the majority of participants had 15-20 years of experience (61.1\%).

Table 1. Distribution of teachers by years of experience

\begin{tabular}{lll}
\hline Years of experience & Number of Participants & Percent \\
\hline less than 5 & 4 & 22.2 \\
$5-10$ & 1 & 5.6 \\
$15-20$ & 11 & 61.1 \\
$25-30$ & 2 & 11.1 \\
Total & 18 & 100.0 \\
\hline
\end{tabular}

Table 2. Distribution of teachers by specialty

\begin{tabular}{lll}
\hline Specialty & Number of Participants & Percent \\
\hline Liter & 9 & 50.0 \\
Ling & 9 & 50.0 \\
Total & 18 & 100.0 \\
\hline
\end{tabular}

Table 2 shows that the percentage of linguistics instructors is equal to that of literature instructors, that is, $50 \%$ for each specialty.

Table 3. Distribution of teachers by the level they teach

\begin{tabular}{lll}
\hline Level & Number of Participants & Percent \\
\hline Level 1 & 7 & 38.9 \\
Level 2 & 5 & 27.8 \\
Level 3 & 3 & 16.7 \\
Level 4 & 3 & 16.7 \\
\hline
\end{tabular}

Table 3 shows the percentage of teachers based on the student levels they teach. Those who teach in the first level constitute $38.9 \%$ of the total participants, while $27.8 \%$ teach in the second level, $16.7 \%$ in the third level, and $16.7 \%$ in the fourth level. 
Table 4. Distribution of teachers by teaching style

\begin{tabular}{lll}
\hline Style & Number of Participants & Percent \\
\hline $\begin{array}{l}\text { All-round flexible } \\
\text { adaptable (S1) }\end{array}$ & 7 & 38.9 \\
$\begin{array}{l}\text { Sensitive } \\
\text { student-centered (S2) }\end{array}$ & 1 & 5.6 \\
$\begin{array}{l}\text { Official curriculum (S3) } \\
\text { Straight facts (S4) }\end{array}$ & 1 & \\
Big conference (S5) & 2 & 5.6 \\
One-off (S6) & 0 & 11.1 \\
Mixed & 5 & 11.1 \\
Mixed (S1+S2) & 2 & 0 \\
literature & & 27.7 \\
Mixed (S1+S5) & 3 & 11.1 \\
linguistics & & 16.6 \\
\hline
\end{tabular}

From Table 4, we can observe that $38.9 \%$ of the participating instructors follow the all-round flexible and adaptable teaching style. The sensitive student-centered and official curriculum styles are adapted by $11.2 \%$ of the instructors (5.6\% for each style), while the straight facts and big conference styles are used by $22.2 \%$ of the participants (11.1\% for each style). None of the participants indicated using the one-off style $(0 \%)$. The analysis also showed a tendency to use a mixed style $(27.7 \%) ; 11.1 \%$ combined styles 1 and 2 , while $16.6 \%$ mixed styles 1 and 5. The instructors of literature preferred a mixture of styles 1 and 2, whereas the linguistics teachers favored a combination of styles 1 and 5 .

Table 5. Relationship between teaching style and specialty

\begin{tabular}{lllll}
\hline \multirow{2}{*}{ Style } & Literature & \multicolumn{3}{c}{ Linguistics } \\
\cline { 2 - 5 } & $\begin{array}{l}\text { Number of } \\
\text { Participants }\end{array}$ & Percent & $\begin{array}{l}\text { Number of } \\
\text { Participants }\end{array}$ & Percent \\
\hline $\begin{array}{l}\text { All-round flexible and } \\
\text { adaptable }\end{array}$ & 5 & 27.8 & 2 & 11.1 \\
$\begin{array}{l}\text { Sensitive } \\
\text { student-centered }\end{array}$ & 0 & 0 & 1 & 5.55 \\
$\begin{array}{l}\text { Official curriculum } \\
\text { Straight facts }\end{array}$ & 1 & 5.55 & 0 & 0 \\
$\begin{array}{l}\text { Big conference } \\
\text { One-off }\end{array}$ & 0 & 0 & 2 & 11.1 \\
Mixed & 0 & 5.55 & 1 & 5.55 \\
\hline
\end{tabular}

As shown in Table 5, 27.8\% of literature teachers, compared to $11.1 \%$ of linguistics teachers, follow the all-round flexible and adaptable style. The sensitive student-centered style and the straight facts style are used only by linguistics teachers $(5.55 \%$ and $11.1 \%$, respectively), while the official curriculum style is used only by literature teachers $(5.55 \%)$. The big conference style is equally preferred by teachers of both specialties $(5.55 \%$ each). Neither linguistics nor literature teachers follow the one-off teaching style. Both groups use mixed styles, but the percentage is higher among linguistics teachers.

The teaching style hexagons shown in Figures 1 and 2 show that literature teachers prefer the all-round flexible style, the mixed style, and the official curriculum and big conference styles successively, whereas linguistics teachers prefer the mixed style, the all-round flexible style straight facts styles, and the student-centered and big conference styles consecutively. 


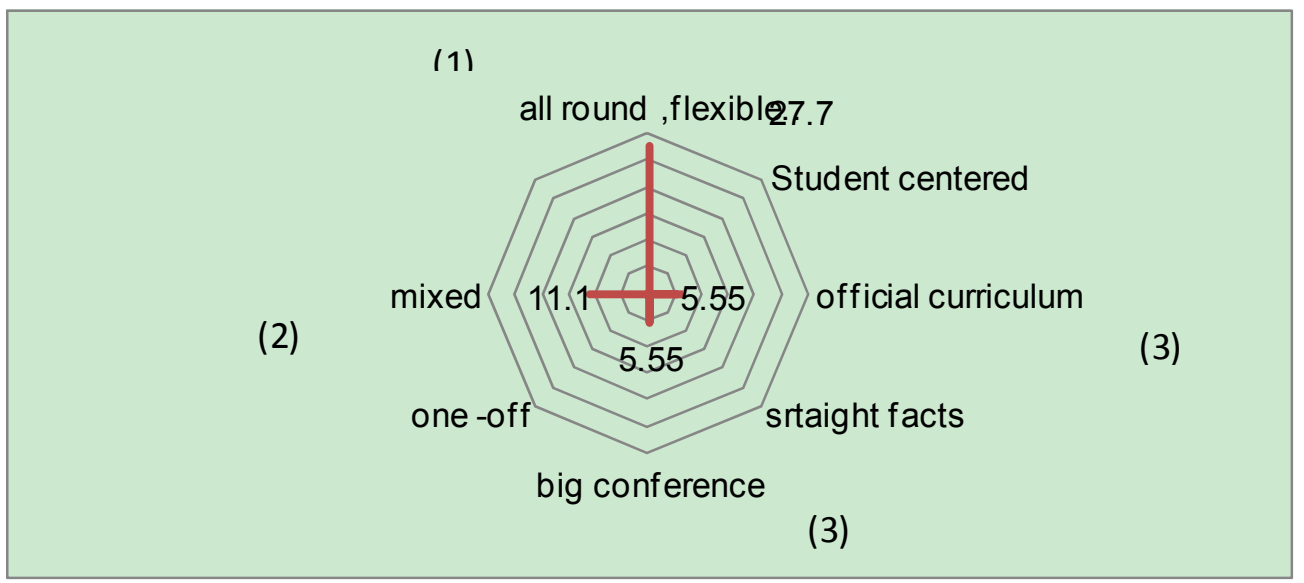

Figure 1. Hexagon plot of literature instructors' teaching styles

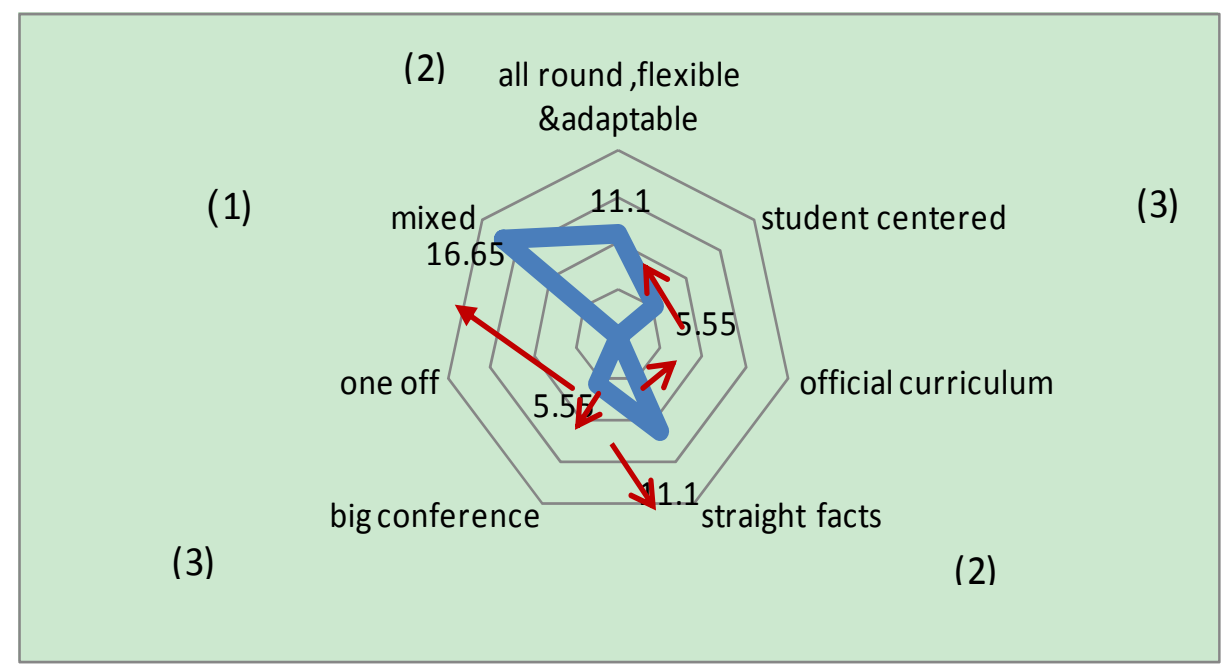

Figure 2. Hexagon plot of linguistics instructors' teaching styles

The last step was to run the Spearman correlation coefficient test to determine the relationship between style on one hand and specialty, student level $(1,2,3$, and 4$)$, years of experience, and age on the other. The data in Tables 6,7 , and 8 indicate that there is no statistically significant correlation between style and specialty, and between style and levels 1 and 2 .

Table 6. Correlation between teaching style and specialization

\begin{tabular}{lll}
\hline Style & Correlation coefficient & Significance level \\
\hline $\begin{array}{l}\text { All-round flexible } \\
\text { and adaptable }\end{array}$ & -.342 & .165 \\
$\begin{array}{l}\text { Sensitive } \\
\text { student-centered }\end{array}$ & .243 & \\
Official curriculum & -.243 & .332 \\
Straight facts & .354 & .332 \\
Big conference & .000 & .150 \\
Style 7 & -.354 & 1.000 \\
Style 8 & .447 & .150 \\
\hline
\end{tabular}


Table 7. Correlation between teaching style and level 1

\begin{tabular}{lll}
\hline Style & Correlation coefficient & Significance level \\
\hline $\begin{array}{l}\text { All-round flexible } \\
\text { and adaptable }\end{array}$ & -.169 & .503 \\
$\begin{array}{l}\text { Sensitive } \\
\text { student-centered }\end{array}$ & $.193-$ & .442 \\
Official & & \\
curriculum & -.193 & .442 \\
Straight facts & .081 & .751 \\
Big conference & .081 & .751 \\
Style 7 & .081 & .751 \\
Style 8 & .255 & .307 \\
\hline
\end{tabular}

Table 8. Correlation between teaching style and level 2

\begin{tabular}{lll}
\hline Style & Correlation coefficient & Significance level \\
\hline $\begin{array}{l}\text { All-round flexible } \\
\text { and adaptable }\end{array}$ & .269 & .281 \\
$\begin{array}{l}\text { Sensitive } \\
\text { student-centered }\end{array}$ & -.150 & \\
Official curriculum & -.150 & .551 \\
Straight facts & .175 & .551 \\
Big conference & -.219 & .486 \\
Style 7 & -.219 & .382 \\
Style 8 & .055 & .382 \\
\hline
\end{tabular}

Table 9. Correlation between teaching style and level 3

\begin{tabular}{lll}
\hline Style & Correlation coefficient & Significance level \\
\hline $\begin{array}{l}\text { All-round flexible } \\
\text { and adaptable }\end{array}$ & -.051 & .841 \\
$\begin{array}{l}\text { Sensitive } \\
\text { student-centered }\end{array}$ & -108 & \\
Official curriculum & $.542^{*}$ & .668 \\
Straight facts & -.158 & .020 \\
Big conference & -.158 & .531 \\
Style 7 & -.158 & .531 \\
Style 8 & .200 & .531 \\
\hline
\end{tabular}

*The correlation is significant at the 0.05 level.

As shown in Table 9, there is a statistically significant correlation between the "curriculum teacher" and level 3. Most of the level three teachers use the official curriculum style. Official curriculum teachers are well prepared and familiar with the materials and how to use them. They are very well trained and have substantial experience in teaching. These facts hold true for the participating teachers since most of them have more than 10 years' teaching experience and are $\mathrm{PhD}$ holders.

Table 10. Correlation between teaching style and level 4

\begin{tabular}{lll}
\hline Style & Correlation coefficient & Significance level \\
\hline $\begin{array}{l}\text { All-round flexible } \\
\text { and adaptable }\end{array}$ & -.051 & .841 \\
$\begin{array}{l}\text { Sensitive } \\
\text { student-centered }\end{array}$ & $.542^{*}$ & \\
Official curriculum & -.108 & .020 \\
Straight facts & -.158 & .668 \\
Big conference & -.158 & .531 \\
Style 7 & .316 & .531 \\
Style 8 & -.200 & .201 \\
\hline
\end{tabular}

*The correlation is significant at the 0.05 level. 
The data in Table 10 indicate that there is a statistically significant correlation between level 4 and the student-centered teaching style. The teachers who follow this style are very student-centered, teach in small groups, and use role play and drama. The style is actually parallel with fourth year students for two reasons: first, these students are graduating very soon so they need to develop their levels of self-direction and independence; and second, they are taking mostly literary courses where they need to practice role play and drama.

Table 11. Correlation between teaching style and years of experience

\begin{tabular}{lll}
\hline Style & Correlation coefficient & Significance level \\
\hline $\begin{array}{l}\text { All-round flexible } \\
\text { and adaptable }\end{array}$ & .000 & 1.000 \\
$\begin{array}{l}\text { Sensitive } \\
\text { student-centered }\end{array}$ & .080 & .751 \\
Official curriculum & .080 & .751 \\
Straight facts & .117 & .643 \\
Big conference & .117 & .643 \\
Style 7 & -.449 & .062 \\
Style 8 & .082 & .745 \\
\hline
\end{tabular}

Table 12. Correlation between teaching style and age

\begin{tabular}{lll}
\hline Style & $\begin{array}{l}\text { Correlation } \\
\text { coefficient }\end{array}$ & Significance level \\
\hline $\begin{array}{l}\text { All-round flexible } \\
\text { and adaptable }\end{array}$ & -.069 & .786 \\
$\begin{array}{l}\text { Sensitive } \\
\text { student-centered }\end{array}$ & .366 & .136 \\
Official curriculum & .146 & .563 \\
Straight facts & .000 & 1.000 \\
Big conference & .160 & .526 \\
Style 7 & -.160 & .526 \\
Style 8 & -.225 & .370 \\
\hline
\end{tabular}

The data in Tables 11 and 12 indicate that there is no statistically significant relationship between teaching style and the variables age and years of experience.

After the data analysis, the teachers were brought together to make them aware of the nature of their preferred teaching styles, including the ways on how to maximize these styles and improve on their least preferred styles. They were encouraged to use mixed styles to meet different objectives and learning needs according to their comfort zone. By exploring other styles, they might discover that their students respond better to multiple teaching styles.

\section{References}

CORD. (2005). Teaching style inventory. Retrieved from http://www.texascollaborative.org/tools/TSI.pdf

Evans, C. (2004). Exploring the relationship between cognitive style and teaching style. Educational Psychology, 24(4), 509-530. http://dx.doi.org/10.1080/0144341042000228870

Felder, M. (1995). Learning and teaching styles in foreign and second language education. Foreign Language Annals, 28(1), 21-31. http://dx.doi.org/10.1111/j.1944-9720.1995.tb00767.x

Grasha, A. F., \& Riechmann, H. S. (1996). Teaching style inventory. Retrieved from http://longleaf.net/teachingstyle.html

Grasha, A. F. (1997). Teaching with style. Pittsburgh, PA: Alliance.

Hargreaves, A. (2003). Teaching in the knowledge society: Education in the age of insecurity. New York: Teachers College Press. 
Heimlich, J. E. (1990). Measuring teaching style: A correlational study between the Van Tilburg/Heimlich Sensitivity Measure and the Myers-Briggs personality indicator on adult educators in central Ohio. Unpublished doctoral dissertation. The Ohio State University.

Jarvis, P. (1985). Thinking critically in an information society: A sociological analysis. Lifelong-Learning, 8(6), $11-14$.

Kaplan, E. J., \& Kies, D. A. (1995). Teaching and learning styles: Which came first? Journal of Instructional Psychology, 22(1), 29-33.

Kulinna, P. H., \& Cothran, D. J. (2003). Physical education teachers' self-reported use and perceptions of various teaching styles. Learning and Instruction, 31(6), 597-609.

Kumaravadivelu, B. (1991). Language-learning tasks: teacher intention and learner interpretation. English Language Teaching Journal, 45(2), 98-107. http://dx.doi.org/10.1093/elt/45.2.98

Lawrence, M. V. M. (1997). Secondary school teachers and learning style preferences: Action or watching in the classroom? Educational Psychology, 17(1-2), 157-170. http://dx.doi.org/10.1080/0144341970170111

Lenz, E. (1982). The art of teaching adults. New York: Holt, Rinehart, and Winston.

May Oi, E. W., \& Stimpson, P. (1994). Teaching styles of Hong Kong's environmental educators in secondary schools. Research in Education, 52(1), 1-12.

Mohanna, K., Chambers, R., \& Wall, D. (2008). Your teaching style: A practical guide to understanding, developing and improving. United Kingdom: Radcliffe Publishing.

Mohanna, K., Chambers, R., \& Wall, D. (2006). Developing your teaching style: Increasing effectiveness in healthcare teaching. Retrieved January 21, 2012, from, http://pmj.bmj.com/content/83/977/145.full.pdf

Opdenakker, M. C., \& Van Damme, J. (2006). Teacher characteristics and teaching styles as effectiveness enhancing factors of classroom practice. Teaching and Teacher Education, 22(1), 1-21. http://dx.doi.org/10.1016/j.tate.2005.07.008

Oxford, R., Ehrman, M., \& Lavine, R. (1991). Style wars: Teacher-student style conflicts in the language classroom. In S. Magnan (Ed.), Challenges in the 1990's for College Foreign Language Programs. Boston: Heinle and Heinle.

Pratt, D. D., \& Collins, J. B. (2001). Teaching perspectives inventory. Retrieved from http://teachingperspectives.com/

Richards, J. C. (1998). Beyond training. Cambridge, UK: Cambridge University Press.

Robinson, R. D. (1979). Helping adults learn and change. Milwaukee, Wis.: Omnibook Company.

Rosenfeld, M., \& Rosenfeld, S. (2007). Developing effective teacher beliefs about learners: the role of sensitizing teachers to individual learning differences (ILDs). Proceedings of the 12th Annual Conference of the European Learning Styles Information Network (pp. 268-292). Trinity College, Dublin, Ireland.

Wallace, B., \& Oxford, R. L. (1992). Disparity in learning styles and teaching styles in the ESL Classroom: Does this mean war? AMTESOL Journal, 1, 45-68.

Walqui, A. (September 27, 2010). Developing teacher expertise to teach English language learners and other students common core standards curricula. Retrieved January 7, 2012, from, http://programs.ccsso.org/projects/ELLCONF/Presentations/CurriculumPedagogy/Developing\%20Teacher $\% 20$ Expertise $\% 20$ doe\%20ELLS.pdf

Zhenhui, R. (July 7, 2001). Matching Teaching Styles with Learning Styles in East Asian Contexts. The Internet TESL Journal, VII(7). Retrieved November 17, 2011, from, http://iteslj.org/Techniques/Zhenhui-TeachingStyles.html 